\title{
PENERAPAN PAJAK PENGHASILAN ATAS DIVIDEN
}

\author{
Irwan Sugiarto \\ Dosen Tetap Sekolah Tinggi Hukum Bandung \\ E-mail : irwan.sugiarto@yahoo.com
}

\begin{abstract}
Tax payment is a mutual agreement among citizens as it is contained in the 1945 Constitution article 23A. Today, tax does not become something strange to society. Some groups of people have already put the tax proportionally in their lives. Tax has already been assumed as one of obligations for every citizen. Referring to the dividend division, there is a tax obligation. The tax levy on dividend refers to taxation principle on revenue in a wide meaning; that is to say tax on dividend which is an obtained or received additional economic capability should pay the tax without referring to where it derives from, to be used for consumption or to add morewealth.

The method of tax levy on dividend is regulated in Act No. 36 year 2008 on the fourth amendment of Act No. 7 year 2000 on Income Tax. The received income referring to article 23 paragraph (1) letter a number 1 is as meant in article 4 paragraph (1) letter $g$ with the tariff as many as $15 \%$ from the total amount by the party who must pay dividend. Then, article 26 with the tax levy as many as $20 \%$ from the total amount by the party who must pay dividend, and article 17 paragraph (2c) with tax levy as many as $10 \%$. Non-tax object is received revenue which is meant in article 4 paragraph (3) letter f; letteri; and letter $k$.
\end{abstract}

Keywords: income tax; dividend;

\begin{abstract}
Abstrak
Membayar pajak merupakan kesepakatan bersama di antara warga negara seperti yang dituangkan di dalam Pasal 23A Undang-undang Dasar (UUD) Tahun 1945. Saat ini pajak bukan lagi merupakan sesuatu yang asing bagi masyarakat. Sebagian kalangan telah menempatkan pajak secara proporsional dalam kehidupannya, bahwa pajak telah dianggap sebagai salah satu kewajiban dalam bernegara. Terkait dengan pembagian dividen, dalam hal ini juga terdapat kewajiban perpajakan. Pengenaan perpajakan untuk dividen menganut prinsip pemajakan atas penghasilan dalam pengertian yang luas, yaitu bahwa pajak atas dividen yang merupakan tambahan kemampuan ekonomis yang diterima atau diperoleh wajib pajak tanpa melihat dari manapun asalnya yang dapat dipergunakan untuk konsumsi atau menambah kekayaan.

Metode pengenaan pajak penghasilan atas dividen diatur dalam Undang-Undang Nomor 36 Tahun 2008 tentang Perubahan Keempat atas Undang-Undang Nomor 7 Tahun 2000 tentang Pajak Penghasilan. Penghasilan yang diterima yang dimaksud dalam Pasal 23 ayat (1) huruf a angka 1 yaitu sebagaimana yang dimaksud dalam Pasal 4 ayat (1) huruf $g$, dengan pengenaan tarif sebesar 15\% (lima belas persen) dari jumlah bruto oleh pihak yang wajib membayarkan dividen. Kemudian Pasal 26, dengan pengenaan tarif sebesar 20\% (dua puluh persen) dari jumlah bruto oleh pihak yang wajib membayarkan dividen, dan Pasal 17 ayat (2c) dengan pengenaan tarif sebesar 10\% (sepuluh persen) dan bersifat final. Yang bukan objek pajak, adalah penghasilan yang diterima yang dimaksud dalam pasal 4 ayat (3) huruf f; huruf i ; dan hurufk.
\end{abstract}

Kata Kunci: Pajak Penghasilan, Dividen Keywords: income tax; dividend; 


\section{A. PENDAHULUAN}

Pembangunan nasional adalah kegiatan yang berlangsung secara terus menerus dan berkesinambungan yang bertujuan untuk meningkatkan kesejahteraan rakyat baik materiil maupun spiritual. Untuk dapat merealisasikan tujuan tersebut, maka pemerintah perlu banyak memperhatikan masalah pembiayaan pembangunan. Salah satu usaha untuk mewujudkan kemandirian suatu bangsa atau negara dalam pembiayaan pembangunan yaitu menggali sumber dana yang berasal dari dalam negeri berupa pajak, kemudian hasil dari pemungutan pajak akan digunakan untuk membiayai pembangunan yang berguna bagi kepentingan dan kesejahteraan bersama.

Pajak dari perspektif ekonomi dipahami sebagai beralihnya sumber daya dari sektor privat kepada sektor publik. Pemahaman ini memberikan gambaran bahwa adanya pajak menyebabkan dua situasi menjadi berubah. Pertama, berkurangnya kemampuan individu dalam menguasai sumber daya untuk kepentingan penguasaan barang dan jasa. Kedua, bertambahnya kemampuan keuangan negara dalam penyediaan barang dan jasa publik yang merupakan kebutuhan masyarakat. $^{2}$

Sementara pemahaman pajak dari perspektif hukum menurut Soemitro merupakan suatu perikatan yang timbul karena adanya undang-undang yang menyebabkan timbulnya kewajiban warga negara untuk menyetorkan sejumlah penghasilan tertentu kepada negara, negara mempunyai kekuatan untuk memaksa dan uang pajak tersebut harus dipergunakan untuk penyelenggaraan pemerintahan. Dari pendekatan hukum ini memperlihatkan bahwa pajak yang dipungut harus berdasarkan undangundang sehingga menjamin adanya kepastian hukum, baik bagi fiskus sebagai pengumpul pajak maupun wajib pajak sebagai pembayar pajak. ${ }^{3}$

Saat ini pajak bukan lagi merupakan sesuatu yang asing bagi masyarakat. Sebagian kalangan telah menempatkan pajak secara proporsional dalam kehidupannya, bahwa pajak telah dianggap sebagai salah satu kewajiban dalam bernegara, yaitu merupakan sarana untuk ikut berpartisipasi dalam membantu pelaksanaan tugas kenegaraan yang ditangani oleh pemerintah. Indikasi ini terlihat dari semakin banyaknya jumlah wajib pajak, demikian juga dengan keikutsertaan masyarakat dari berbagai kalangan. Hal ini dapat dilihat apabila ada suatu penyelenggaraan kegiatan mengenai perpajakan, seperti halnya seminar, dialog, penyuluhan, dan sebagainya. Selain itu juga dapat dilihat dengan makin banyaknya buku-buku mengenai perpajakan, serta berbagai kolom atau rubrik khusus tentang perpajakan di berbagai mass media. Namun juga tidak dapat dipungkiri bahwa sebagian masyarakat juga belum memahami tentang hukum perpajakan. ${ }^{4}$

P.J.A. Adriani ${ }^{5}$ menyatakan bahwa:

"Pajak adalah iuran kepada negara

\footnotetext{
Waluyo dan B. Ilyas Wirawan, Perpajakan Indonesia, Salemba Empat, Cetakan II, Jakarta, 2000, hlm . 2

"Pajak", http://id.wikipedia.org/wiki/Pajak, diakses tanggal 10 Januari 2014

Ibid.
} 
(yang dapat dipaksakan) terutang oleh yang wajib membayarnya menurut peraturan-peraturan, dengan tidak mendapat prestasi kembali, yang langsung dapat ditunjuk, dan yang gunanya adalah untuk membiayai pengeluaran-pengeluaran umum berhubung dengan tugas negara untuk menyelenggarakan pemerintahan".

Pengertian pajak yang disebutkan Prof. Adriani sejalan dengan Pasal 1 ayat (1) Undang-Undang Nomor 28 Tahun 2007 tentang Perubahan Ketiga atas Undangundang Nomor 6 Tahun 1983 tentang Ketentuan Umum dan Tata Cara Perpajakan (KUP) yang menyatakan: ${ }^{6}$

"Pajak adalah kontribusi wajib kepada negara yang terutang oleh orang pribadi atau badan yang bersifat memaksa berdasarkan undangundang, dengan tidak mendapat imbalan secara langsung dan digunakan untuk keperluan negara bagi sebesar-besarnya kemakmuran rakyat".

Berdasarkan pengertian di atas, secara singkat dapat dikatakan bahwa pajak adalah iuran kepada negara. Sebuah iuran yang wajar, mengingat negara dan mereka yang membayar iuran sesungguhnya saling membutuhkan. Iuran yang disetor kepada negara itu digunakan untuk menjalankan berbagai kewajiban negara, seperti pelayanan publik, menjaga keamanan dan pertahanan serta menyelenggarakan pemerintahan yang baik. Lazimnya sebuah perikatan, maka ada pihak yang berhak mendapatkan sesuatu dan ada pihak lain yang wajib memenuhi hak tersebut, begitu pula sebaliknya. Dengan demikian pajak merupakan perikatan antara Fiscus (negara sebagai pemungut pajak yang diwakili Direktorat Jenderal Pajak) dengan wajib pajak sebagai pembayar pajak, dan masing-masing pihak mempunyai hak sekaligus kewajiban. Tetapi tidak seperti perikatan jual beli, hubungan timbal balik dalam perikatan pajak tidak bersifat sempurna, sebab pihak wajib pajak sebagai pembayar pajak hanya mempunyai kewajiban, tanpa mempunyai hak untuk memperoleh kontraprestasi (imbalan) langsung, sedangkan fiscus hanya mempunyai hak, yaitu hak memungut pajak tanpa mempunyai kewajiban. Kontraprestasi yang diterima pembayar pajak dari fiscus bersifat tidak langsung, melainkan dijalankan oleh negara, berupa pelayanan publik, pemeliharaan pertahanan dan keamanan. ${ }^{7}$

Melihat kenyataan tersebut, kadang timbul pertanyaan : jika tidak ada imbalan langsung, mengapa harus membayar pajak? Jawabannya adalah membayar pajak merupakan kesepakatan bersama di antara warga negara seperti yang dituangkan di dalam Pasal 23A Undangundang Dasar (UUD) Tahun 1945 dan Amandemennya ditegaskan: "Pajak dan pungutan lain yang bersifat memaksa

\footnotetext{
Liberty Pandiangan, Pemahaman Praktis Undang-Undang Perpajakan Indonesia, Erlangga, Jakarta, 2002, hlm. 2.

R. Santoso Brotodihardjo, Pengantar Ilmu Hukum Pajak, Refika Aditama, Bandung, 2008, hlm. 2.

Undang-Undang No. 28 Tahun 2007 tentang Perubahan Ketiga atas Undang-Undang No. 6 Tahun 1983 tentang Ketentuan Umum dan Tata Cara Perpajakan

Koperasi Pegawai KP DJP, Tinjauan Perpajakan Indonesia, Gemilang Gagasanido Handal, Jakarta, 2006, hlm. 2.
} 
untuk keperluan negara diatur dengan undang-undang”. Dengan demikian, membayar pajak adalah memenuhi kewajiban yang tertera di dalam UUD 1945 dan melaksanakan amanat rakyat itu sendiri.

Dilihat dari sejarahnya, sejak Indonesia merdeka pada tahun 1945, ketentuan pemungutan pajak di Indonesia dapat dibagi menjadi dua periode:

1. periode ordinasi, dimana pemerintah masih menggunakan ketentuanketentuan dari zaman penjajahan (ordonansi) untuk memungut pajak,

2. periode reformasi perpajakan 1983, dilakukan pada awal tahun 1980-an melalui Pembaruan Sistem Perpajakan Nasional (PSPN).

Pada periode ordonansi, banyak jenis pajak yang wajib dibayar masyarakat sehinga menimbulkan kebingungan dan beban pajak berganda. Maka berbagai jenis pajak direformasi melalui Pembaruan Sistem Perpajakan Nasional (PSPN) yang menghasilkan dua paket undang-undang perpajakan yang merupakan produk asli Indonesia. Paket I terdiri dari Undangundang No. 6 Tahun 1983 tentang Ketentuan Umum dan Tata Cara Perpajakan (KUP); Undang-undang No. 7 Tahun 1983 tentang Pajak Penghasilan; Undang-undang No. 8 Tahun 1983 tentang Pajak Pertambahan Nilai (PPN) dan Pajak Penjualan Barang Mewah (PPnBM), sedangkan paket II terdiri dari dua undangundang, yaitu Undang-undang No. 12 Tahun 1985 tentang Pajak Bumi dan Bangunan (PBB); dan Undang-undang No. 13 Tahun 1985 tentang Bea Materai (BM).
Secara historis, hingga saat ini pemerintah telah melakukan perubahanperubahan atas undang-undang perpajakan yang ada (yaitu tahun 1983, 1985, 1994, 1997 dan 2000 serta 2007). Hal ini menunjukkan bahwa peraturan perpajakan Indonesia cukup akomodatif, dinamis dan antisipatif dalam mengamati, mengkaji dan menerapkan perkembangan yang terjadi di luar perpajakan-seperti perkembangan ekonomi, moneter, industri dan perdagangan, bahkan perkembangan sosial, politik, teknologi dan sebagainyauntuk disesuaikan pengaturan perpajakannya. ${ }^{8}$

Dalam praktiknya tidak semua negara berhasil mengenakan, menarik dan memungut pajak, karena ada juga masyarakat yang menolak atau bahkan melakukan pemberontakan demi menolak pajak. Dapat ditengok catatan sejarah, seperti : salah satu pemicu meletusnya Revolusi Perancis dan Revolusi Amerika Serikat dua abad silam adalah masalah pajak. Dalam Revolusi Amerika, pajak diangkat menjadi slogan umum pemberontakan, yakni No Taxation without Representation, dengan maksud bahwa warga Amerika enggan membayar pajak jika mereka tidak memiliki wakil di lembaga legislatif. Kegagalan pemungutan pajak ini bisa terjadi jika penerapan pajak tidak berdasarkan kepada asas-asas maupun prinsip-prinsip dasar perpajakan yang berlaku secara universal. Hal ini juga berkaitan erat dengan perkembangan tata kelola pemerintahan, sehingga pengelolaan pajak oleh negara atau pemerintah, harus mengacu kepada

Liberty Pandiangan, Op.Cit., hlm. 3. 
prinsip-prinsip Good Governance. ${ }^{9}$

Bila dicermati pendapat masyarakat tentang pajak seperti yang acap muncul di media massa, secara umum dapat disimpulkan bahwa masih banyak anggota masyarakat yang belum mengetahui atau memahami hakikat dan fungsi dari pajak, baik bagi kehidupan negara maupun kehidupan masyarakat sendiri. Pembayaran pajak umumnya dipandang sebagai suatu kewajiban (satu arah) kepada negara, lantaran ciri khas pajak adalah dapat dipaksakan kepada masyarakat, tanpa masyarakat memperoleh imbalan balik secara langsung. Pandangan yang kurang luas ini mengakibatkan pajak hanya dianggap sebagai beban semata. Padahal bila diteliti lebih jauh, pajak yang telah diterima negara juga menjadi hak masyarakat, artinya bahwa masyarakat memperoleh kembali pajak itu tanpa terkecuali dalam bentuk lain, yakni melalui penyediaan berbagai barang dan jasa publik (public goods and services). Hal ini bisa dipahami secara mendalam melalui sistem keuangan negara. Secara teoritis dan praktis dapat dilihat bahwa pajak memiliki beberapa fungsi dalam kehidupan negara dan masyarakat, yaitu :

1. fungsi budgeter, untuk kelangsungan hidup negara, seluruh komponen tugas-tugas negara, apakah itu pemerintah (eksekutif), pengawasan (legislatif) maupun penegakan hukum (yudikatif) harus dapat melaksanakan tugasnya dengan baik. Agar rencana tersebut berjalan dengan baik, tentu harus didukung dana yang cukup. Di
Indonesia, rencana penyediaan dana dan barang serta jasa publik terangkum dalam APBN tiap tahun. Oleh karena penyediaan dana ini menyangkut budgeter, sesuai dengan ketentuan yang berlaku, pelaksanaannya harus dibahas lebih dulu oleh pemerintah dengan Dewan Perwakilan Rakyat (DPR), kemudian disetujui DPR.

2. fungsi regulerend, pemerintah mengatur segala sesuatu yang berada di dalam wilayahnya. Melalui pengaturan ini pemerintah dapat melaksanakan tugasnya, baik dalam rangka melayani masyarakat dan mewujudkan masyarakat yang adil dan makmur.

3. fungsi distribusi, dapat dibagi dua, yaitu:

a. berdasarkan sektor dijalankan oleh instansi pemerintah sesuai dengan tugas pokoknya, seperti bidang kesehatan, pendidikan, keamanan, dan lainnya,

b. berdasarkan wilayah dilakukan melalui pembagian anggaran belanja untuk masing-masing daerah.

4. fungsi demokrasi, keikut-sertaan masyarakat dalam pengelolaan negara merupakan hal mutlak, sehingga segala kegiatan negara dapat direncanakan dan diarahkan guna kemakmuran dan kesejahteraan masyarakat. $^{10}$

Meningkatnya hasil yang diperoleh pemerintah di bidang perpajakan hingga saat ini, baik itu dari aspek budgeter, tingkat kesadaran dan kepatuhan, maupun

Ibid, hlm. 70. 
pemahaman masyarakat, tidaklah lepas dari upaya reformasi perpajakan (tax reform) dan penerapan prinsip-prinsip good governance yang dilakukan oleh pemerintah sejak pertama sekali tahun 1983. Dilihat dari segi waktu, saat pelaksanaan reformasi perpajakan pertama kali tersebut sangatlah tepat, sebagai upaya reposisi andalan dalam penerimaan negara. Karena di tengah iklim perekonomian nasional yang terpengaruh saat itu akibat kemerosotan harga minyak di pasar internasional, telah membawa dampak yang cukup berarti bagi penerimaan negara. Lebih dari itu, Indonesia bukanlah satu-satunya negara yang melakukan reformasi perpajakan pada kurun waktu itu, karena dilakukan juga oleh banyak negara. Hal ini sesuai dengan penelitian Richard A Musgrave yang menyatakan bahwa tahun 1980-an merupakan dekade reformasi perpajakan. ${ }^{11}$

Penyelenggaraan pemerintahan dan pembangunan berkesinambungan memerlukan dana untuk pengeluaran rutin dan pembangunan yang bersumber dari pemerintah dan masyarakat. Pengeluaran rutin sedapat mungkin dipenuhi dari hasil pajak, sedangkan pembangunan dibiayai dari tabungan, apakah itu tabungan pemerintah maupun tabungan masyarakat. Kewenangan pemungutan dan pengelolaan pajak oleh pemerintah pusat diserahkan kepada Direktorat Jenderal Pajak sebagai instansi di bawah Departemen Keuangan sesuai dengan undang-undang dan peraturan perpajakan yang berlaku. Pajak jenis ini dikenal sebagai pajak pusat, sebaliknya pajak yang menjadi kewenangan pemerintah daerah dikenal sebagai pajak daerah.

Jenis-jenis pajak pusat yang menjadi kewenangan Direktorat Jenderal Pajak tersebut, meliputi :

\section{Pajak Penghasilan (PPh),} merupakan pajak yang dikenakan atas penghasilan yang diterima atau diperoleh seseorang atau badan usaha dalam tahun pajak.

Dalam terminologi pajak, seseorang atau badan usaha yang menerima atau memperoleh penghasilan dikenal sebagai Subjek Pajak. Subjek Pajak Penghasilan terdiri dari Orang Pribadi, Badan Usaha-termasuk Badan Usaha milik Pemerintah-yang secara umum disebut sebagai Badan, serta Bentuk Usaha Tetap (BUT). Penjelasan lebih rinci tentang jenis subjek pajak penghasilan dapat dilihat berikut ini :

\section{a. Orang Pribadi}

1) orang pribadi yang bertempat tinggal di Indonesia atau orang pribadi yang berada di Indonesia lebih dari 183 hari dalam jangka waktu 12 bulan atau orang pribadi yang dalam suatu tahun pajak berada di Indonesia dan mempunyai niat untuk bertempat tinggal di Indonesia. ${ }^{12}$

2) orang pribadi yang tidak bertempat tinggal di Indonesia atau berada di Indonesia kurang dari 183 hari dalam jangka waktu

\footnotetext{
${ }^{10}$ Koperasi Pegawai KP DJP, Op.Cit, hlm. 73.

${ }^{11}$ Liberty Pandiangan, Op.Cit, hlm. 2.
} 
12 bulan yang menjalankan kegiatan usaha atau melakukan kegiatan usaha melalui Bentuk Usaha Tetap di Indonesia. ${ }^{13}$

3) orang pribadi yang tidak bertempat tinggal di Indonesia atau berada di Indonesia kurang dari 183 hari dalam jangka waktu 12 bulan yang dapat menerima atau memperoleh penghasilan dari Indonesia bukan dari menjalankan kegiatan usaha atau melakukan kegiatan usaha melalui Bentuk Usaha Tetap (BUT). ${ }^{14}$

4) warisan yang belum terbagi sebagai satu kesatuan menggantikan yang berhak. ${ }^{15}$

\section{b. Badan}

1) badan yang didirikan atau berkedudukan seperti Perseroan Terbatas (PT), Commanditter Veenotschap (CV), perseroan lainnya, Badan Usaha Milik Negara (BUMN)/Badan Usaha Milik Daerah (BUMD) dengan nama dan bentuk apapun, firma, kongsi, koperasi, dana pensiun, persekutuan, perkumpulan, yayasan, organisasi massa, organisasi sosial politik, atau organisasi yang sejenis, lembaga dan bentuk badan lainnya.

2) badan yang tidak didirikan dan tidak bertempatkedudukan di Indonesia. ${ }^{16}$

\section{c. Bentuk Usaha Tetap}

Bentuk usaha yang digunakan oleh orang pribadi yang tidak bertempat tinggal atau berada di Indonesia kurang dari 183 hari dalam jangka waktu 12 bulan atau yang digunakan oleh badan yang tidak didirikan dan tidak bertempat kedudukan di Indonesia untuk menjalankan kegiatan usaha atau melakukan kegiatan di Indonesia, seperti kantor cabang, kantor perwakilan, pabrik, gedung kantor dan orang atau badan usaha yang bertindak sebagai agen yang tidakindependen. ${ }^{17}$

Subjek pajak menjadi wajib pajak apabila memenuhi kriteria subjek pajak sebagaimana tercantum di atas, dan memenuhi kriteria kewajiban objektif, yaitu apabila yang bersangkutan telah menerima atau memperoleh penghasilan yang dikenakan pajak sesuai dengan ketentuan Pajak Penghasilan, yaitu Undang-Undang Nomor 36 Tahun 2008 tentang Pajak Penghasilan. Kewajiban subjektif dipenuhi, antara lain dengan mendaftarkan diri untuk memperoleh Nomor Pokok Wajib Pajak (NPWP), sedangkan kewajiban objektif dipenuhi dengan pembayaran dan pelaporan pajak yang terutang. ${ }^{18}$

2. Pajak Pertambahan Nilai (PPN) dan Pajak Penjualan Barang Mewah (PPnBM), adalah pajak atas konsumsi barang dan/atau jasa yang dikenakan pajak di dalam daerah pabean

\footnotetext{
${ }_{12}$ Pasal 2 ayat (3) butir a Undang-Undang No. 36 Tahun 2008 tentang PPh.

${ }_{13}$ Pasal 2 ayat (4) butir a Undang-Undang No. 36 Tahun 2008 tentang PPh.

${ }_{14}$ Pasal 2 ayat (4) butir b Undang-Undang No. 36 Tahun 2008 tentang PPh.

${ }_{15}$ Pasal 2 ayat (3) butir c Undang-Undang No. 36 Tahun 2008 tentang PPh.

${ }_{16}$ Pasal 2 ayat (3) butir b Undang-Undang No. 36 Tahun 2008 tentang PPh.

${ }_{17}$ Pasal 2 ayat (5) Undang-Undang No. 36 Tahun 2008 tentang PPh.
} 
Indonesia.

Dalam terminologi perpajakan, barang dan jasa yang dikenakan $\mathrm{p}$ ajak berdasarkan Undang-undang Nomor 8 Tahun 1983 s.t.d.d. Undang-Undang Nomor 18 Tahun 2000 tentang PPN dan PPnBM. Atas Barang dan Jasa disebutkan dengan istilah Barang Kena Pajak (BKP) dan Jasa Kena Pajak (JKP), sedangkan PPnBM merupakan pajak konsumsi tambahan yang dikenakan atas penyerahan dan/atau impor BKP yang tergolong mewah.

3. Pajak Bumi dan Bangunan (PBB), adalah pajak yang dikenakan atas tanah (bumi) dan/atau bangunan yang berada di wilayah Republik Indonesia yang diatur dalam Undang-undang Nomor 12 Tahun 1985 s.t.d.d. Undangundang Nomor 12 Tahun 1994 tentang Pajak Bumi dan Bangunan.

4. Bea Materai adalah pajak atas dokumen yang dipakai masyarakat di dalam lalu-lintas hukum, yang diatur dalam Undang-undang Nomor 13 Tahun 1985 tentang Bea Materai.

5. Bea Perolehan Hak atas Tanah dan Bangunan (BPHTB) merupakan bentuk pajak yang dikenakan pada setiap peristiwa pengalihan hak atas tanah dan bangunan, yang diatur dalam Undang-undang Nomor 21 Tahun 1997 s.t.d.d. Undang-undang Nomor 20 Tahun 2000 tentang Bea Peolehan Hak atas Tanah dan Bangunan (BPHTB). ${ }^{19}$
Menurut ajaran materiil, bahwa timbulnya utang pajak adalah karena bunyi undang-undang saja, tanpa diperlukan suatu perbuatan manusia (jadi sekalipun tidak dikeluarkan surat ketetapan pajak oleh fiscus asalkan dipenuhi syarat terdapatnya suatu Taatbestand yang terdiri dari keadaan-keadaan tertentu dan atau juga peristiwa ataupun perbatasan tertentu. ${ }^{20}$ Tidak demikian halnya dengan para penganut ajaran formal, yang mengaitkan timbulnya utang pajak dengan dikeluarkannya surat ketetapan pajak. ${ }^{21}$

Bagaimanapun juga dapatlah dimengerti bahwa penting sekali, baik buat negara maupun buat para wajib pajak, untuk dapatnya segera ditentukan jumlah utang pajaknya, dan pekerjaan ini menjadi tugas Direktorat Jenderal Pajak, dan hal ini sesuai undang-undang perpajakan hasil reformasi 1983 mengubah pendekatan pemungutan pajak dari sistem official assessment menjadi sistem self assessment, yakni wajib pajak diberi tanggung jawab dan kewajiban untuk menghitung, membayar dan melaporkan pajak-pajak yang menjadi kewajibannya. ${ }^{22}$

Terkait dengan pembagian dividen, dalam hal ini juga terdapat kewajiban perpajakan, yaitu sesuai dengan Undangundang Nomor 36 Tahun 2008 tentang Pajak Penghasilan. Kata dividen berasal dari bahasa Inggris, yang memiliki arti pembagian keuntungan atas saham. ${ }^{23}$ Menurut Kamus Besar Bahasa Indonesia arti dividen adalah :

"bagian laba atau pendapatan perusahaan

\footnotetext{
${ }_{18}$ Pasal 2 Undang-Undang No. 28 Tahun 2007 tentang Ketentuan Umum dan Tata Cara Perpajakan.

${ }^{19}$ Koperasi Pegawai KP DJP, Op.Cit., hlm. 17-34

${ }^{20}$ R. Santoso Brotodihardjo, Op.Cit., hlm. 116
} 
yang besarnya ditetapkan oleh direksi serta disahkan oleh rapat pemegang saham untuk dibagikan kepada para pemegang saham, atau sejumlah uang yang berasal dari keuntungan yang dibayarkan kepada pemegang saham sebuah perseroan. ${ }^{24}$

Dividen secara umum adalah merupakan bagian laba yang diperoleh pemegang saham atau pemegang polis asuransi atau pembagian sisa hasil usaha koperasi yang diperoleh anggota koperasi. $^{25}$

Termasuk dalam pengertian dividen ini adalah: ${ }^{26}$

1. pembagian laba baik secara langsung ataupun tidak langsung, dengan nama dan dalam bentuk apapun;

2. pembayaran kembali karena likuidasi yang melebihi jumlah yang disetor;

3. pemberian saham bonus yang dilakukan tanpa penyetoran termasuk saham bonus yang berasal dari kapitalisasi agio saham;

4. pembagian laba dalam bentuk saham;

5. pencatatan tambahan modal yang dilakukan tanpa penyetoran;

6. jumlah yang melebihi jumlah setoran sahamnya yang diterima atau diperoleh pemegang saham karena pembelian kembali saham-saham oleh perseroan yang bersangkutan;

7. pembayaran kembali seluruhnya atau sebagian dari modal yang disetorkan, jika dalam tahun-tahun yang lampau diperoleh keuntungan, kecuali jika pembayaran kembali itu adalah akibat dari pengecilan modal dasar (statuter) yang dilakukan secara sah;

8. pembayaran sehubungan dengan tanda-tanda laba, termasuk yang diterima sebagai penebusan tandatanda laba tersebut;

9. bagian laba sehubungan dengan pemilikan obligasi;

10. bagian laba yang diterima oleh pemegang polis;

11. pembagian berupa sisa hasil usaha kepada anggota koperasi;

12. pengeluaran perusahaan untuk keperluan pribadi pemegang saham yang dibebankan sebagai biaya perusahaan.

Kata dividen berkaitan erat dengan saham atau modal dalam hukum perusahaan / perseroan, sedangkan perusahaan/perseroan dalam istilah perpajakan dikenal dengan istilah badan, sehingga apabila kita membaca bunyi Pasal 1 angka 3 Undang-undang Nomor 28 Tahun 2007 tentang Ketentuan Umum dan Tata Cara Perpajakan ditegaskan bahwa :

"Badan adalah sekumpulan orang dan/atau modal yang merupakan kesatuan baik yang melakukan usaha maupun yang tidak melakukan usaha yang meliputi perseroan terbatas, perseroan komanditer, perseroan lainnya, badan usaha milik negara atau badan usaha milik daerah

\footnotetext{
${ }^{21}$ Ibid, hlm. 119.

${ }^{22}$ Koperasi Pegawai KP DJP, Op.Cit., hlm. 11.

${ }^{23}$ John M. Echols and Hasan Shadily, An English-Indonesian Dictionary, Gramedia, Jakarta, 2003, hlm. 191.

${ }^{24}$ Departemen Pendidikan Nasional, Kamus Besar Bahasa Indonesia, Balai Pustaka, Jakarta, 2007, hlm. 271.

25 A. Syarifuddin Alsah, Pemotongan-Pemungutan Pajak Penghasilan, Kharisma Bintang Kreativitas Prima, Jakarta, 2002, hlm. 95.

${ }^{26}$ Pasal 4 ayat (1) huruf g Undang-undang No. 36 Tahun 2008 tentang Perubahan Keempat atas Undang-Undang No. 7 Tahun 1983 tentang Pajak Penghasilan.
} 
dengan nama dan dalam bentuk apapun, firma, kongsi, koperasi, dana pensiun, persekutuan, perkumpulan, yayasan, organisasi massa, organisasi sosial politik, atau organisasi lainnya, lembaga dan bentuk badan lainnya termasuk kontrak investasi kolektif dan bentuk usaha tetap". ${ }^{27}$

Pengenaan perpajakan untuk dividen sebagaimana diuraikan di atas menganut prinsip pemajakan atas penghasilan dalam pengertian yang luas, yaitu bahwa pajak atas dividen yang merupakan tambahan kemampuan ekonomis yang diterima atau diperoleh wajib pajak tanpa melihat dari manapun asalnya yang dapat dipergunakan untuk konsumsi atau menambah kekayaan. ${ }^{28}$

Hal ini sesuai dengan yang diatur dalam pasal 4 ayat (1) Undang-undang Nomor 36 Tahun 2008 tentang Perubahan Keempat atas Undang-undang Nomor 7 Tahun 1983 tentang Pajak Penghasilan yang menyatakan bahwa yang menjadi objek pajak adalah penghasilan, yaitu setiap tambahan kemampuan ekonomis yang diterima atau diperoleh wajib pajak, baik yang berasal dari Indonesia maupun dari luar Indonesia yang dapat dipakai untuk konsumsi atau menambah kekayaan wajib pajak yang bersangkutan, dengan nama dan dalam bentuk apapun.

Berdasarkan pada uraian di atas, tulisan ini akan membahas masalah: Bagaimanakah metode pengenaan pajak penghasilan atas dividen?

\section{B. PEMBAHASAN}

\section{Metode Pengenaan Pajak Atas Penghasilan}

Perlakuan pajak penghasilan atas dividen yang diterima atau diperoleh oleh Wajib Pajak Orang Pribadi (WP OP) dalam negeri mengacu pada metode one tier dan pengenaan pajaknya bersifat final, maksudnya adalah untuk mendorong perusahaan membagikan dividen kepada pemegang sahamnya sehingga hal tersebut akan menstimulasi bertumbuhnya kegiatan perekonomian dan investasi di Indonesia dan juga untuk menyederhanakan administrasi perpajakan bagi Wajib pajak maupun DirektoratJenderal Pajak (Ditjen Pajak). ${ }^{29}$

Menurut Hector S. de Leon, terdapat 3 (tiga) prinsip dasar dari suatu sistem perpajakan yaitu: ${ }^{30}$

1) Kecukupan pajak (fiscal adequacy)

Menurut prinsip ini, sumber penghasilan secara keseluruhan harus memadai sebagai sumber bagi anggaran negara. Hal ini berarti penghasilan harus elastis atau mampu berkontraksi setiap tahunnya untuk menjawab keperluan pengeluaran negara. Sebagai alternatifnya adalah :

a) adanya resiko dari defisit atau surplus anggaran karena ketidak-elastisan penghasilan; atau

b) menyesuaikan jumlah pengeluaran negara terhadap aliran/arus dana yang ada dengan membatasi atau mengurangi kegiatan tertentu, sehingga anggaran yang ada dapat secara optimal dimanfaatkan.

Elastisitas diperoleh tanpa membuat pengenaan pajak baru setiap tahun, tetapi dengan mengubah tarif yang dapat diterapkan atas pajak yang telah

\footnotetext{
${ }^{27}$ Undang-undang No. 28 Tahun 2007 tentang Ketentuan Umum dan Tata Cara Perpajakan

${ }^{28}$ Majalah Berita Pajak, Vol. XLI No.1633,15 April 2009
} 
ada.

2) Kesamaan atau teori keadilan (equiality or theoretical justice)

Dengan prinsip ini, suatu beban pajak harus proporsional dengan kemampuan yang dimiliki wajib pajak untuk membayar pajak. Prinsip ini akan menciptakan kondisi di mana kewajiban setiap orang terhadap pemenuhan anggaran negara dibagi secara adil.

3) Kelayakan administrasi (adminitrative feasibility)

Menurut prinsip kelayakan administrasi, setiap peraturan harus mampu menciptakan adminitrasi yang mudah, adil, dan efektif. Dalam hal ini, setiap sistem perpajakan harus jelas dan mudah dilaksanakan oleh Wajib pajak maupun petugas (fiscus), harus memiliki keserasian antara waktu pembayaran, tempat, dan cara pembayaran, serta tidak terlalu membebankan atau menghambat kegiatan usaha.

Mengapa rakyat harus dipaksa memberikan uang kepada negara dalam bentuk pajak? Jawabannya ada di beberapa teori terhadap pembenaran dari segi hukum (rechtvaardiging) terhadap pemungutan pajak.

Teori-teori tersebut adalah sebagai berikut: ${ }^{31}$

1) Teori Asuransi, merupakan teori tertua tentang pembenaran pemungutan pajak. Teori ini mengajarkan bahwa pembayaran pajak sama dengan pembayaran premi dalam asuransi. Inti dari teori ini adalah bahwa negara menjamin dan melindungi jiwa raga dan harta dari rakyat, dan karenanya rakyat harus membayar premi berupa pajak kepada negara.

2) Teori Daya Pikul (draagkrecht), merupakan teori yang mengajarkan bahwa besarnya pajak yang dipungut dari seorang wajib pajak haruslah sesuai dengan kemampuan pembayaran (daya pikul) dari wajib pajak. Yang dimaksud dengan daya pikul di sini adalah kekuatan seseorang untuk memikulvbeban dari apa yang tersisa setelah seluruh penghasilannya dikurangi dengan pengeluaranpengeluaran yang mutlak untuk kehidupan primer dirinya dan keluarga yang ditanggungnya.

3) Teori Keseimbangan (equivalentie), disebut juga dengan teori kepentingan (belangen theorie) mengajarkan bahwa seorang individu mempunyai kepentingan atas pekerjaan negara. Semakin banyak seseorang mengenyam kepentingannya dari negara, semakin besar pula pajak yang harus dibayarnya.

4) Teori Daya Beli, mengajarkan bahwa pemungutan pajak akan menyedot daya beli masyarakat, tetapi dapat dibenarkan karena hasil pajak tersebut akan dikembalikan juga kepada masyarakat dalam bentukyang lain.

5) Teori Kewajiban Pajak Mutlak (absolute belastingplicht), atau sering

\footnotetext{
${ }^{29}$ Majalah Berita Pajak, Vol.XLI No. 1622, 1 November 2008, hlm. 12.

${ }^{30}$ Liberty Pandiangan, Op.cit; hlm. 23.

${ }^{31}$ Munir Fuady, Pengantar Hukum Bisnis, Citra Aditya Bakti, Bandung, 2005, hlm. 275.
} 
juga disebut "teori pengorbanan" ini mengajarkan bahwa negara mempunyai hak mutlak untuk memungut pajak dari warganya, sementara rakyat wajib patuh dan melakukan pengorbanan untuk membayar pajak tersebut.

Untuk dapat mencapai tujuan dari pemungutan pajak, beberapa ahli mengemukakan beberapa asas dalam pemungutan pajak, antara lain: ${ }^{32}$

a. Menurut Adam Smith dalam bukunya Wealth of Nations dengan ajaran yang terkenal "The Four Maxims", asas pemungutan pajak adalah sebagai berikut:

- Asas Equality (asas keseimbangan dengan kemampuan atau asas keadilan): pemungutan pajak yang dilakukan oleh negara harus sesuai dengan kemampuan dan penghasilan wajib pajak. Negara tidak boleh bertindak diskriminatif terhadap wajib pajak.

- Asas Certainty (asas kepastian hukum): semua pungutan pajak harus berdasarkan UU, sehingga bagi yang melanggar akan dapat dikenai sanksi hukum.

- Asas Convinience of Payment (asas pemungutan pajak yang tepat waktu atau asas kesenangan): pajak harus dipungut pada saat yang tepat bagi wajib pajak (saat yang paling baik), misalnya disaat wajib pajak baru menerima penghasilannya atau disaat wajib pajak menerima hadiah.

- Asas Effeciency (asas efesien atau asas ekonomis): biaya pemungutan pajak diusahakan sehemat mungkin, jangan sampai terjadi biaya pemungutan pajak lebih besar dari hasil pemungutan pajak.

b. Menurut W.J. Langen, asas pemungutan pajak adalah sebagai berikut:

- Asas daya pikul: besar kecilnya pajak yang dipungut harus berdasarkan besar kecilnya penghasilan wajib pajak. Semakin tinggi penghasilan maka semakin tinggi pajak yang dibebankan.

- Asas manfaat: pajak yang dipungut oleh negara harus digunakan untuk kegiatan-kegiatan yang bermanfaat untuk kepentingan umum.

- Asas kesejahteraan: pajak yang dipungut oleh negara digunakan untuk meningkatkan kesejahteraan rakyat.

- Asas kesamaan: dalam kondisi yang sama antara wajib pajak yang satu dengan yang lain harus dikenakan pajak dalam jumlah yang sama (diperlakukan sama).

- Asas beban yang sekecil-kecilnya: pemungutan pajak diusahakan sekecil - kecilnya (serendahrendahnya) jika dibandinglan sengan nilai obyek pajak. Sehingga tidak memberatkan para wajib pajak.

c. Menurut Adolf Wagner, asas pemungutan pahak adalah sebagai

32 “Pajak", http://id.wikipedia.org/wiki/Pajak, diakses tanggal 15 Januari 2014. 
berikut:

- Asas politik finalsial : pajak yang dipungut negara jumlahnya memadadi sehingga dapat membiayai atau mendorong semua kegiatan negara

- Asas ekonomi: penentuan obyek pajak harus tepat Misalnya: pajak pendapatan, pajak untuk barangbarang mewah

- Asas keadilan yaitu pungutan pajak berlaku secara umum tanpa diskriminasi, untuk kondisi yang sama diperlakukan sama pula.

- Asas administrasi: menyangkut masalah kepastian perpajakan (kapan, di mana harus membayar pajak), keluwesan penagihan (bagaimana cara membayarnya) dan besarnya biaya pajak.

- Asas yuridis segala pungutan pajak harus berdasarkan UndangUndang.

\section{Metode Pengenaan Pajak atas Dividen}

\section{a. Pemajakan atas Dividen di Indonesia}

Pemajakan atas dividen di Indonesia dikenal beberapa metode antara lain metode klasik dan metode integrasi. Pengecualian penerapan metode klasik diberlakukan atas dividen yang dibagikan kepada Wajib pajak badan (legal person) yang merupakan Perseroaan Terbatas yaitu Wajib pajak dalam negeri, koperasi, badan usaha milik negara, atau badan usaha milik daerah, dengan syarat:

1) dividen berasal dari cadangan laba yang ditahan; dan

2) bagi peseroan terbatas, badan usaha milik negara dan badan usaha milik daerah yang menerima dividen, kepemilikan saham pada badan yang memberikan dividen paling rendah 25 $\%$ (dua puluh lima persen) dari jumlah modal yang disetor dan harus mempunyai usaha aktif di dluar kepemilikan saham tersebut.

Selanjutnya, untuk mencegah timbulnya distorsi dalam perekonomian, timbulnya pajak berganda (double taxation) harus dapat dicegah dalam penerapan metode pemajakan atas dividen, maka pelaksanaan metode tersebut: $:^{33}$

1) Pada metode klasik, perusahaan yang membagikan dividen dan pemegang saham merupakan 2 (dua) entitas yang berbeda sehingga dividen yang dibagikan kepada pemegang saham merupakan objek pajak dan wajib dipotong pajak penghasilannya oleh perusahaan yang membagikan dividen. Selanjutnya pajak penghasilan yang dilunasi di muka oleh pemegang saham melalui mekanisme pemotongan pajak dapat dikreditkan atas pajak penghasilan yang terutang di akhir tahun. Maksudnya adalah untuk mencegah timbulnya pengenaan pajak berganda pada penerima dividen.

2) Sesuai metode integrasi, laba usaha yang diterima atau diperoleh oleh perusahaan yang membagikan dividen dengan dividen yang diterima atau diperoleh pemegang saham dianggap bersumber dari satu penghasilan yang sama. Karena atas laba bersih telah dikenakan pajak penghasilan (disebut sebagai corperate income tax), 
selanjutnya laba bersih yang telah dikenakan pajak tersebut ketika dibagikan dalam bentuk dividen kepada pemegang saham tidak dikenakan pajaklagi.

Pada umumnya dalam Undang-Undang Nomor 36 Tahun 2008 tentang Pajak Penghasilan diterapkan metode klasik atas dividen yang diterima atau diperoleh oleh pemegang saham, pengecualian penerapan metode klasik diberlakukan atas dividen yang ditentukan dalam Pasal 4 ayat (3) Undang-Undang Nomor 36 Tahun 2008 tentang Pajak Penghasilan. Dengan demikian, metode integrasi diterapkan atas pembagian dividen terhadap wajib pajak badan yang memenuhi syarat sebagaimana dimaksud di atas. $^{34}$

\section{b. Pemajakan atas Pembagian Dividen Sesuai Tax Treaty}

Tax treaty merupakan perjanjian pajak bilateral antar dua negara mitra runding yang bersepakat untuk mengatur pembagian hak pemajakanya atas penghasilan yang diterima atau diperoleh oleh penduduk (residence taxpayer) dari salah satu negara mitra runding atau kedua negara mitra runding, dengan tujuan untuk mencegah timbulnya pengenaan pajak berganda (double taxation) dan memerangi timbulnya pengelakan pajak (tax evation).

Pengenaan pajak berganda dicegah dengan membatasi hak pemajakan dari negara sumber (source country) yaitu negara di mana penghasilan tersebut timbul. Dengan demikian, hak pemajakan atas penghasilan yang timbul diberikan kepada negara domisili yaitu negara di mana si Penerima penghasilan terdaftar sebagai penduduk. Namun untuk melindungi kepentingan penerimaan dari negara sumber yang berasal dari pajak, pengecualian di atas diberikan dalam hal penduduk dari negara mitra runding lainnya memperoleh penghasilan melalui Bentuk Usaha Tetap-nya (BUT) di negara sumber. Selain itu, hak pemajakan terbatas (limited tax rights) juga diberikan atas penghasilan pasif (passive income) yaitu dividen, bunga dan royalti.

Sehubungan dengan pembagian hak pemajakan atas penghasilan dividen diatur bahwa prinsipnya hak pemajakan diberikan kepada negara domisili.

Namun untuk melindungi kepentingan penerimaan dari negara sumber, maka dapat diberikan hak pemajakan atas penghasilan tersebut secara terbatas kepada negara sumber.

Selanjutnya, batasan hak pemajakan dimaksud sesuai dengan kesepakatan dari kedua negara mitra runding dan umumnya dituangkan dalam Perjanjian Penghindaran Pajak Berganda (P3B), ${ }^{35}$ sebagaimana terlihat pada tabel 2 di bawah ini:

\footnotetext{
Majalah Berita Pajak, Vol.XLI No. 1622,1 November 2008, hlm. 13

${ }^{34}$ Ibid.

35 Majalah Berita Pajak, Vol.XLI No. 1622, 01 November 2008
} 
Tabel. 2

Daftar Penghindaran Pengenaan

Pajak Berganda

\begin{tabular}{|c|c|c|}
\hline Negara & Portofolio & $\begin{array}{c}\text { Penyertaan } \\
\text { Langsung }\end{array}$ \\
\hline $\begin{array}{l}\text { Algeria, Australia, } \\
\text { Egypt, Norway }\end{array}$ & $15 \%$ & $15 \%$ \\
\hline $\begin{array}{l}\text { China, Democratic } \\
\text { Peoples's Republic of } \\
\text { Korea, Kuwait,Sudan. } \\
\text { Syria, USA, Slovak }\end{array}$ & $10 \%$ & $10 \%$ \\
\hline $\begin{array}{l}\text { Austria, Belgium, } \\
\text { Canada, France, } \\
\text { Germany, India, } \\
\text { Pakistan, Poland, } \\
\text { South Africa, Spain, } \\
\text { Switzerland, Ukraine, } \\
\text { UK, } \\
\text { Uzbekistan,Venezuela, }\end{array}$ & $15 \%$ & $10 \%$ \\
\hline $\begin{array}{l}\text { Brunei Darussalam, } \\
\text { Bulgaria, Vietnam }\end{array}$ & $15 \%$ & $15 \%$ \\
\hline Czech & $15 \%$ & $10 \%$ \\
\hline Denmark & $20 \%$ & $10 \%$ \\
\hline $\begin{array}{l}\text { Finland, Singapore, } \\
\text { Sweden, Turkey }\end{array}$ & $15 \%$ & $10 \%$ \\
\hline $\begin{array}{l}\text { Hungary, New Zeland, } \\
\text { Tahiland, Philipinnes }\end{array}$ & $15 \%$ & $15 \%$ \\
\hline Italy & $15 \%$ & $10 \%$ \\
\hline Jordan & $10 \%$ & $10 \%$ \\
\hline Malaysia, Russia & $15 \%$ & $15 \%$ \\
\hline Netherlands & $15 \%$ & $10 \%$ \\
\hline Romania & $15 \%$ & $12,5 \%$ \\
\hline Seychelles & $10 \%$ & $10 \%$ \\
\hline Sri Lanka & $15 \%$ & $10 \%$ \\
\hline Taiwan & $10 \%$ & $10 \%$ \\
\hline Tunisia & $12 \%$ & $12 \%$ \\
\hline UEA & $10 \%$ & $10 \%$ \\
\hline
\end{tabular}

Sumber : Tax Treaty Indonesia dengan neged ainnitgartanitdapupentima dividen yang merupakan penduduk dari negara mitra runding dengan penduduk dari non mitra runding, perlakuan pajak penghasilannya berbeda. Sesuai dengan sovereignty rule, perbedaan perlakuan pajak penghasilan atas dividen yang diterima atau diperoleh oleh para penerima dividen dimungkinkan. Namun untuk menyelaraskan dengan international best practice, maka aspek level of playing field dan non discriminative rule seyogianya tetap dipertahankan dalam pembuatan kebijakan pajak penghasilan.

\section{Hak dan Kewajiban Perpajakan atas} Pembagian Dividen

a. Kewajiban Perpajakan atas Pembagian Dividen

Kewajiban utama dari Wajib pajak adalah pembayaran pajak itu sendiri. Di samping kewajiban utama tersebut, Wajib pajak juga memiliki kewajiban-kewajiban yang khusus dan teknis, yaitu sebagai berikut: $^{36}$

1) kewajiban untuk mendaftarkan diri dan meminta nomor pokok wajib pajak (NPWP),

2) mengambil sendiri blangko surat pemberitahuan pajak (SPT),

3) mengisi SPT dengan benar dan lengkap,

4) menghitung dan menetapkan sendiri jumlah yang harus dibayar. Ini sebagai akibat dari berlakunya prinsip self assessment, yang membebankan kewajiban menghitung dan menetapkan besarnya pajak pada Wajib pajak itu sendiri,

5) memperlihatkan pembukuan dan data lain yang diperlukan oleh petugas pajak.

\section{b. Hak Perpajakan atas Dividen}

Keseimbangannya, Wajib pajak juga memiliki hak-hak tertentu. Hak-hak Wajib pajak yang umum adalah untuk menerima kembali secara tidak langsung manfaat dari uang pembayaran pajak tersebut, misalnya lewat program sosial atau pembangunan yang dilaksanakan oleh pemerintah dari biaya hasil pajak tersebut. Di samping hak-hak yang umum tersebut,

\footnotetext{
${ }^{36}$ Munir Fuady, Op.Cit., hlm. 280
} 
Wajib pajak juga memiliki hak-hak yang khusus dan teknis, yaitu sebagai berikut: ${ }^{37}$

1) hak untuk menerima Surat Pemberitahuan Pajak (SPT),

2) hak untuk mengajukan penundaan pengajuan SPT,

3) hak untuk melakukan pembetulan sendiri atas SPT yang sudah dimasukkan,

4) hak untuk mengajukan permohonan penundaan dan pengangsuran pembayaran pajak sesuai kemampuan,

5) hak untuk memperoleh pengembalian kelebihan pembayaran pajak,

6) hak untuk memperoleh kepastian batas ketetapan pajakyang terutang,

7) hak untuk mengajukan surat keberatan pajak.

8) hak untuk mengajukan permohonan banding surat keputusan atas surat keberatan pajak.

\section{Pelaksanaan Pajak Penghasilan atas Pembagian Dividen}

Adapun arah dan tujuan pajak penghasilan adalah untuk lebih meningkatkan keadilan pengenaan pajak, lebih memberikan kemudahan kepada Wajib pajak, dan menunjang kebijakan Pemerintah dalam rangka meningkatkan investasi langsung di Indonesia melalui penanaman modal asing maupun penanaman modal dalam negeri di bidang-bidang usaha tertentu dan daerahdaerah tertentu yang mendapat prioritas. ${ }^{38}$

Pembayaran pajak atas pembagian dividen untuk orang pribadi, akan mengurangi penghasilan/pendapatan yang siap untuk dikonsumsi. Namun berkurangnya penghasilan ini tidak serta merta menurunkan daya belinya secara mutlak, karena batasan yang dianggap cukup proporsional. Sedangkan bagi dunia usaha, penghasilan/pendapatan yang siap dikonsumsi jumlahnya tidak berkurang, karena pajak penghasilan dipungut setelah dikurangi dengan biaya-biaya yang dikeluarkan dunia usaha untuk melaksanakan kegiatan usahanya. ${ }^{39}$

Berdasarkan Peraturan Menteri Keuangan Republik Indonesia Nomor 256/PMK.03/2008 pada tanggal 31 Desember 2008 tentang penetapan saat diperolehnya dividen oleh Wajib pajak dalam negeri atas penyertaan modal pada badan usaha di luar negeri selain badan usaha yang menjual sahamnya di bursa efek, dinyatakan:

\section{Pasal 1}

Saat diperolehnya dividen oleh Wajib pajak dalam negeri atas penyertaan modal, pada badan usaha di luar negeri selain badan usaha yang menjual sahamnya di bursa efek adalah:

1) pada bulan keempat setelah berakhirnya batas waktu kewajiban penyampaian surat pemberitahuan tahunan Pajak Penghasilan badan usaha di luar negeri tersebut untuk tahun pajak yang bersangkutan; atau

2) pada bulan ketujuh setelah tahun pajak berakhir apabila badan usaha di luar negeri tersebut tidak memiliki kwajiban untuk menyampaikan surat pemberitahuan tahunan Pajak Penghasilan atau tidak ada ketentuan

\footnotetext{
${ }^{37}$ Ibid, hlm. 281.

${ }^{38}$ Majalah Berita Pajak, Vol.XLI No. 1627, 15 Januari 2009, hlm. 23

${ }^{39}$ Koperasi Pegawai Kantor Pusat DirektoratJenderal Pajak, Op.cit; hlm. 74
} 
batas waktu penyampaian surat pemberitahuan tahunan Pajak Penghasilan.

\section{Pasal 2}

Wajib pajak dalam negeri sebagaimana dimaksud dalam Pasal 1 adalah Wajib pajak dalam negeri yang:

1) memiliki penyertaan modal paling rendah 50\% (lima puluh persen) dari jumlah saham yang disetor pada badan usaha di luar negeri; atau

2) secara bersama-sama dengan Wajib pajak dalam negeri lainnya memiliki penyertaan modal paling rendah $50 \%$ (lima puluh persen) dari jumlah saham yang disetor pada badan usaha di luar negeri.

\section{Pasal 3}

1) Besarnya dividen yang wajib dihitung oleh Wajib pajak dalam negeri sebagaimana dimaksud dalam Pasal 2 adalah sebesar jumlah dividen yang menjadi haknya terhadap laba bersih setelah pajak yang sebanding dengan penyertaannya pada badan usaha di luar negeri selain badan usaha yang menjual sahamnya di bursa efek.

2) Ketentuan sebagaimana dimaksud pada ayat (1) tidak berlaku apabila sebelum batas waktu sebagaimana dimaksud dalam Pasal 1, badan usaha di luar negeri dimaksud sudah membagikan dividen yang menjadi hak Wajib pajak.

3) Dividen sebagaimana dimaksud pada ayat (1) atau pada ayat (2) wajib dilaporkan dalam Surat Pemberitahuan Tahunan Pajak Penghasilan untuk tahun pajak saat dividen tersebut dianggap diperoleh.

\section{Pasal 4}

1) Dalam hal Wajib pajak dalam negeri sebagaimana dimaksud dalam Pasal 2 menerima pembagian dividen dalam jumlah yang melebihi jumlah dividen yang dilaporkan sebagaimana dimaksud dalam Pasal 3 ayat (1), atas kelebihan jumlah dividen terebut wajib dilaporkan dalam Surat Pemberitahuan Tahunan Pajak Penghasilan pada tahun pajak dibagikannya dividen tersebut.

2) Dalam hal Wajib pajak dalam negeri menerima pembagian dividen selain dividen sebagaimana dimaksud dalam Pasal 3 ayat (1), dividen tersebut wajib dilaporkan dalam surat Pemberitahuan Tahunan Pajak Penghasilan pada tahun pajak dibagikannya dividen tersebut.

\section{Pasal 5}

1) Pajak atas dividen yang telah dibayar atau dipotong di luar negeri dapat dikreditkan sesuai dengan ketentuan sebagaimana dimaksud dalam Pasal 24 Undang-Undang Nomor 7 Tahun 1983 tentang Pajak Penghasilan sebagaimana telah beberapa kali diubah terakhir dengan UndangUndang Nomor 36 Tahun 2008.

2) Pengkreditan pajak yang dibayar atau dipotong sebagimana dimaksud pada ayat (1) dilakukan pada tahun pajak dibayarnya atau dipotongnya pajak tersebut.

\section{Pasal 6}

Ketentuan mengenai:

1) tata cara pelaporan penerimaan dividen dari luar negeri sebagaimana dimaksud dalam Pasal 1;

2) tata cara perhitungan besarnya pajak yang harus dibayar oleh Wajib pajak 
dalam negeri sebagaimana dimaksud dalam Pasal 2; dan

3) tata cara pengkreditan pajak sebagaimana dimaksud dalam Pasal 5, diatur dengan Peraturan Direktur Jenderal Pajak.

\section{PENUTUP}

\section{Kesimpulan}

a. Metode pengenaan pajak penghasilan atas dividen diatur dalam UndangUndang Nomor 36 Tahun 2008 tentang Perubahan Keempat atas UndangUndang Nomor 7 Tahun 2000 tentang Pajak Penghasilan terbagi atas dua jenis, yaitu :

a. yang merupakan objek pajak, adalah penghasilan yang diterima yang dimaksud dalam:

1) pasal 23 ayat (1) huruf a angka 1 yaitu sebagaimana yang dimaksud dalam pasal 4 ayat (1) huruf g, dengan pengenaan tarif sebesar 15\% (lima belas persen) dari jumlah bruto oleh pihak yang wajib membayarkan dividen,

2) pasal 26, dengan pengenaan tarif sebesar $20 \%$ (dua puluh persen) dari jumlah bruto oleh pihak yang wajib membayarkan dividen, dan

3) pasal 17 ayat (2c) dengan pengenaan tarif sebesar $10 \%$ (sepuluh persen) dan bersifat final.

b. yang bukan objek pajak, adalah penghasilan yang diterima yang dimaksud dalam pasal 4 ayat (3) huruf f ; huruf i ; dan hurufk. b. Kepentingan kepastian hukum pajak pada dasarnya lebih mengutamakan pada kepentingan pemenuhan kewajiban perpajakan oleh masyarakat dan pengamanan penerimaan negara, bukannya pada maksud untuk memenjara, menyandera atau menghukum pembayar pajak. Kepentingan kepastian dan keadilan haruslah lebih ditujukan pada kemanfaatan dan kepentingan penerimaan pajak itu sendiri, yang pada umumnya digunakan untuk keperluan negara bagi sebesar - besarnya kemakmuran masyarakat. Landasan filosofi hukum pajak yang demikian akan memberikan manfaat bagi kepentingan peneriman pajak dan kepastian hukum pajak. Namun tidak dapat dipungkiri bahwa masih banyak terdapat pihak - pihak yang melakukan perlawanan untuk tidak melaksanakan kewajiban perpajakan, baik secara tidak sengaja maupun secara kesengajaan. Demi menciptakan kepastian dan rasa keadilan hukum serta mengamankan penerimaan negara maka bagi para pelanggar ketentuan perpajakan diancam pidana kurungan sesuai dengan Pasal 38 dan Pasal 39 Undang-Undang Nomor 28 Tahun 2007 tentang Ketentuan Umum dan Tata Cara Perpajakan.

\section{Saran}

1. Pembagian dividen umumnya didasarkan atas akumulasi laba, yaitu 
laba ditahan, atas beberapa pos modal lainnya, yang merupakan tambahan penghasilan bagi si penerima, namun hendaknya prosedur pembagian dividen ini telah melaksanakan prinsip - prinsip pengelolaan perusahaan (good corporate governance) yang bermanfaat, antara lain:

a. pemastian adanya perlindungan atas hak-hak pemilik saham baik pemilik saham minoritas maupun asing, dan pemastian diberlakukannya kontrak yang adil dengan penyedia sumber daya/bahan;

b. pengklarifikasian peran dan tanggung jawab pengelola serta usaha-usaha yang dapat membantu memastikan kepentingan pengelolaan dan kepentingan pemilik saham;

c. pemastian bahwa perusahaan memenuhi kewajiban hukum dan peraturan lainnya yang menggambarkan penilaian masyarakat yaitu di bidang trasparansi, kejujuran, dan mampu bertanggung jawab.

2. Reformasi perpajakan yang dilakukan pemerintah akan mampu memperbaiki citra Direktorat Jenderal Pajak di mata masyarakat. Diharapkan masyarakat akan sangat bersahabat dengan pajak dan akhirnya mau membayar pajak secara sukarela sesuai ketentuan dan sistem yang berlaku, seperti modernisasi administrasi perpajakan dan pembentukan Kantor Pelayanan Pajak Modern (Large Tax Office (LTO), Madya
Tax Office (MT0), dan Small Tax Office (STO)), memberikan harapan bahwa Direktorat Jenderal Pajak akan mampu menyediakan pelayanan yang prima bagi masyarakat. Layanan itupun sejalan dengan kerangka good governance. Dengan demikian, seluruh potensi pajak dapat tergali, baik secara prosedural maupun secara sistem informasi.

\section{DAFTAR PUSTAKA}

\section{Buku-buku :}

A. Sonny Keraf, Etika Bisnis,Kanisius, Yogyakarta, 1998

A. Syarifuddin Alsah, PemotonganPemungutan Pajak Penghasilan, Kharisma Bintang Kreativitas Prima, Jakarta, 2002

Alvi Syahrin, Pengaturan dan Kebijakan Pembangunan Perumahan dan Pemukiman Berkelanjutan, Pustaka Bangsa Press, Medan, 2003

Amiruddin dan H. Zainal Asikin, Pengantar Metode Penelitian Hukum, Raja Grafindo Persada, Jakarta, 2004

Bismar Nasution, Hukum Kegiatan Ekonomi I, Book Terrace \& Library, Bandung, 2007

Burhan Bungin, Pemahaman Filosofis dan Metodologis ke Arah Penguasaan Model Aplikasi, Raja Grafindo Persada, Jakarta, 2003

Chatamarrasjid, Penyingkapan Tabir Perseroan (Piercing The Corporate Veil), Citra Aditya Bakti, Bandung, 
2000

Gunawan Widjaja, Hak Individu \& Kolektif

Para Pemegang Saham, Forum Sahabat, Jakarta, 2008

Henry Simamora, Akuntansi Basis Pengambilan Keputusan Bisnis, Salemba Empat, Jakarta, 2000

H.R.Otje Salman S., Teori Hukum, Refika Aditama, Bandung, 2007

J.J.H. Bruggink, Refleksi Tentang Hukum, Citra Aditya Bakti, Bandung, 1999

Jaka Wasana dan Kirbrandoko, DasarDasar Manjemen Keuangan I, Alfabeta, Bandung, 1993

John M. Echols and Hasan Shadily, An English - Indonesian Dictionary, Gramedia, Jakarta, 2003

Kieso, Donald E, and Jerry J. Weygandt, Intermediate Accounting, 7th edition, John Willey and Sons, Inc,

Koperasi Pegawai KP DJP, Tinjauan Perpajakan Indonesia, Gemilang Gagasanido Handal, Jakarta, 2006

L. Thian Hin, Panduan Berinvestasi Saham, Gramedia, Jakarta, 2001

Liberty Pandiangan, Pemahaman Praktis Undang - Undang Perpajakan Indonesia, Erlangga, Jakarta, 2002

Munir Fuady, Pengantar Hukum Bisnis, Citra Aditya Bakti, Bandung, 2005

P. Joko Subagyo, Metode Penelitian dalam Teori dan Praktek, Rineka Cipta, Jakarta, 2004
R. Santoso Brotodihardjo, Pengantar Ilmu Hukum Pajak, Refika Aditama, Bandung, 2008

Ronny H. Soemitro, Metodologi Penelitian Hukum, Ghalia, Jakarta, 1982

Satjipto Rahardjo, Ilmu Hukum, Citra Aditya Bakti, Bandung, 2006

Smith, Jay M. dan Skousen, K Fred, Akuntansi Intermediate, Erlangga, Jakarta, 1993

Soerjono Soekanto, Penegakan Hukum, Binacipta, Jakarta, 1983 Pengantar Penelitian Hukum, Universitas Indonesia, Jakarta, 1984

Suad Husnan dan Enny Pudjiastuti, Dasardasar Manajemen Keuangan, UPP YKPN, Yogyakarta, 1998

Theo Huijbers, Filsafat Hukum Dalam Lintasan Sejarah, Kanisius, Yogyakarta, 1982

\section{B. Perundang-undangan}

Keputusan Menteri Keuangan No. 541/KMK.04/2000

Peraturan Menteri Keuangan Republik Indonesia Nomor 256/PMK.03/2008 tentang Penetapan Saat Diperolehnya Dividen oleh Wajib Pajak Dalam Negeri atas Penyertaan Modal pada Badan Usaha di Luar Negeri selain Badan Usaha yang Menjual Sahamnya di Bursa Efek.

Undang-Undang Nomor 28 Tahun 2007 tentang Perubahan Ketiga atas Undang-Undang Nomor 6 Tahun 1983 
tentang Ketentuan Umum dan Tata Cara Perpajakan

Undang-Undang Nomor 36 Tahun 2008 tentang Perubahan Keempat atas Undang- Undang Nomor 7 Tahun 1983 tentang Pajak Penghasilan

Undang-Undang Nomor 40 Tahun 2007 tentang Perseroan Terbatas

Undang-Undang Nomor 25 Tahun 2007 tentang Penanaman Modal

\section{Majalah dan Informasi Lain}

Berita internet, http://elon. bahanajar. umb.co.id

Berita internet, http: // saptohermawan. staffhukum. uns.ac.id

Kamus Besar Bahasa Indonesia

Majalah Berita Pajak, Vol. XLI No. 1622, 1 November 2008 , Vol. XLI No. 1625, 15 Desember 2008 , Vol. XLI No. 1627, 15 Januari 2009 ,Vol. XLI No. 1633, 15 April 2009

"Pajak", http://id.wikipedia.org/wiki/ Pajak, diakses tanggal 30 November 2014 